\title{
Pengaruh Likuiditas Dan Kepemilikan Institusional Terhadap Kebijakan Dividen Perusahaan Manufaktur
}

\author{
Ni Putu Nugraheni ${ }^{1}$ \\ Made Mertha ${ }^{2}$ \\ ${ }^{1,2}$ Fakultas Ekonomi dan Bisnis Universitas Udayana (Unud), Bali, Indonesia \\ e-mail: nugrahenii19@gmail.com
}

\begin{abstract}
ABSTRAK
Investor memutuskan untuk berinvestasi pada suatu perusahaan untuk mendapatkan keuntungan atau timbal balik investasi baik berupa dividen atau capital gain. Perusahaan harus melakukan pertimbangan mengenai kebijakan dividen yang akan dilakukan karena keputusan mengenai pembagian dividen akan menjadi bahan pertimbangan investor sebelum melakukan investasi. Penelitian ini bertujuan untuk mendapatkan bukti empiris mengenai pengaruh likuiditas dan kepemilikan institusional terhadap kebijakan dividen. Penelitian ini dilakukan pada perusahaan manufaktur yang terdaftar Bursa Efek Indonesia tahun 2014-2017. Metode penentuan sampel yang digunakan adalah menggunakan purposive sampling dengan kriteria perusahaan manufaktur yang membagikan dividen dan mengungkapkan informasi struktur kepemilikan periode 2014-2017 sehingga diperoleh 144 pengamatan. Teknik analisis data yang digunakan yaitu regresi linear berganda. Berdasarkan hasil penelitian, diketahui bahwa likuiditas yang diproksikan dengan current ratio berpengaruh positif dan signifikan terhadap kebijakan dividen. Likuiditas yang diproksikan dengan cash ratio berpengaruh negatif dan tidak signifikan terhadap kebijakan dividen. Kepemilikan institusional berpengaruh positif dan signifikan terhadap kebijakan dividen.
\end{abstract}

Kata Kunci: likuiditas, kepemilikan institusional, kebijakan dividen.

\begin{abstract}
Investors decide to invest in a company to get a profit in the form of dividends or capital gains. The company must consider the dividend policy that will be made because the decision on dividend distribution will be taken into consideration by investors before making an investment. This study aims to obtain empirical evidence regarding the effect of liquidity and institutional ownership on dividend policy. This research was conducted at a listed manufacturing company in 2014-2017. The method of determining the sample used is using purposive sampling. The data analysis technique used is multiple linear regression. Based on the results of the study, liquidity proxied by the current ratio has a positive and significant effect on dividend policy. Liquidity proxied by cash ratio has a negative and not significant effect on dividend policy. Institutional ownership has a positive and significant effect on dividend policy.
\end{abstract}

Keywords: liquidity, institutional ownership, dividend policy.

\section{PENDAHULUAN}

Investor memutuskan untuk berinvestasi pada suatu perusahaan untuk mendapatkan keuntungan atau timbal balik investasi baik berupa dividen atau capital gain. Capital gain adalah pengembalian investasi yang didapat pemegang 
Ni Putu Nugraheni dan Made Mertha. Pengaruh...

saham saat harga saham pada saat penjualan lebih tinggi dibandingkan harga saham pada saat pembelian. Pembagian dividen berisiko lebih rendah dibandingkan dengan capital gain, karena pembagian dividen akan diterima pemegang saham setiap akhir periode, sedangkan pendapatan dari capital gain hanya dapat diperoleh pada saat penjualan saham (Wicaksono dan Nasir, 2014).

Jumlah dividen yang dibagikan perusahaan bergantung dari kebijakan atau aturan yang ditetapkan perusahaan. Setiap perusahaan memiliki kebijakan yang berbeda-beda karena belum adanya aturan yang mengatur mengenai besaran kebijakan dividen yang harus dibayarkan. Keputusan mengenai apakah perusahaan akan membagikan dividen atau tidak, serta besaran dividen yang akan dibayarkan diputuskan pada Rapat Umum Pemegang Saham (RUPS). Pembagian dividen menjadi pertimbangan karena akan berpengaruh pula kepada pembiayaan investasi pada periode berikutnya. Oleh karena itu, perusahaan harus dapat mengoptimalkan kebijakan dividen yang dilakukan serta memikirkan faktor internal dan eksternal yang akan mempengaruhi dan dipengaruhi (Yasmita dan Widanaputra, 2018).

Likuiditas menunjukkan kemampuan perusahaan untuk memenuhi kewajiban keuangannya yang harus segera dipenuhi, atau kemampuan perusahaan untuk memenuhi kewajiban keuangan pada saat ditagih (Sari dan Hidayat, 2017). Alat-alat pembayaran yang diperlukan untuk melunasi kewajiban jangka pendek tersebut harus bernilai lebih besar dibandingkan dengan kewajiban lancar yang dimiliki perusahaan. Kebijakan dividen merupakan salah satu kewajiban lancar 
yang harus dipenuhi perusahaan kepada para pemegang saham perusahaan (Bamaisyarah dan Fuadati, 2017).

Kepemilikan yang presentasenya paling besar dalam perusahaan biasanya adalah kepemilikan oleh pihak institusional. Tingginya tingkat kepemilikan oleh institusi akan meningkatkan pengawasan yang dilakukan oleh investor sebagai pemegang saham, yang bertujuan agak tidak terjadinya perilaku oportunistik yang mungkin dilakukan manajer. Shleifer dan Vishny (1997) berpendapat bahwa pemegang saham dari pihak institusional akan meningkatkan kinerja perusahaan karena institusional memiliki wewenang untuk mengawasi pengambilan keputusan yang dilakukan perusahaan.

Fenomena yang terjadi, terdapat beberapa perusahaan yang tidak membagikan dividen kepada pemegang saham karena laba pada periode tersebut menurun. PT Vale Indonesia Tbk (INCO) memutuskan untuk tidak membagikan keuntungan (dividen) kepada pemegang saham untuk tahun buku 2016 karena keuangan perusahaan memburuk pada periode tersebut (cnnindonesia.com). Pada kasus lain yang terjadi di Anak Usaha PT Lippo Karawaci Tbk, PT Gowa Makassar Tourism Development Tbk, perusahaan ini tetap melakukan pembagian dividen kepada para pemegang saham walaupun pendapatan dan laba perusahaan pada periode tersebut menurun dibandingkan periode sebelumnya (tempo.co).

Penelitian sebelumnya terkait pengaruh likuiditas dan kepemilikan institusional terhadap kebijakan dividen menyimpulkan hasil yang berbeda. Penelitian yang dilakukan oleh Nufiati dan Suwitho (2015), Wahyuni (2015), dan Ahmed (2015) yang menyimpulkan bahwa likuiditas berpengaruh positif terhadap 
Ni Putu Nugraheni dan Made Mertha. Pengaruh...

kebijakan dividen. Di sisi lain Michaely dan Qian (2017) serta Wicaksono dan Nasir (2014) dalam penelitiannya menyimpulkan likuiditas berpengaruh negatif terhadap kebijakan dividen.

Penelitian sebelumnya terkait kepemilikan institusional yang dilakukan oleh Sari dan Budiasih (2016) serta Mehrani et al., (2011) menyimpulkan bahwa kepemilikan institusional berpengaruh negatif terhadap kebijakan dividen. Sedangkan penelitian Kurniawati dkk. (2015) dan (Jory et al., 2017) menyimpulkan bahwa kepemilikan institusional berpengaruh positif terhadap kebijakan dividen.

Teori keagenan yang dikemukakan oleh Jensen dan Meckling (1976) mengungkapkan bahwa hubungan keagenan ada hubungan yang terjadi antara prinsipal (pemegang saham) yang memperkejakan agen (manajemen perusahaan) untuk mewakili pengambilan keputusan dalam perusahaan. Manajemen perusahaan atau yang disebut dengan agen akan cenderung untuk membuat keputusan yang cenderung menguntungkan dirinya sendiri. Di sisi lain, pemegang saham tidak memiliki kemampuan untuk mengawasi aktivitas manajemen setiap harinya untuk memastikan bahwa agen bekerja tidak hanya untuk kepentingannya sendiri, namun juga sesuai dengan keinginan pemegang saham selaku investor (Anthony dan Govindarajan, 2012). Dalam struktur kepemilikan saham, terdapat kelompok pemegang saham pengendali dan pemegang saham non pengendali. Pemegang saham pengendali berperan untuk memonitor kinerja manajer perusahaan agar tidak bertindak untuk kepentingannya sendiri, melainkan juga untuk pemegang saham. Di sisi lain, pemegang saham pengendali menginginkan 
agar keputusan yang diambil manajemen menguntungkan dirinya seperti melakukan pembagian dividen khusus kepada pemegang saham pengendali, yang akan merugikan pemegang saham non pengendali. Oleh karena itu, akan tejadi masalah keagenan di antara pemegang saham pengendali dan juga pemegang saham non pengendali. Konflik yang terjadi tersebut dijelaskan sebagai Agency Problem II (Villalonga dan Amit, 2006) atau Type II Agency Costs (Bozec dan Laurin, 2008).

Teori sinyal menurut Brigham dan Houston (2010:185), adalah sebuah aktivitas atau tindakan yang dilakukan perusahaan guna meberikan petunjuk mengenai pandangan manajemen terhadap prospek perusahaan. Sinyal atau isyarat tersebut dijadikan sebagai petunjuk untuk investor sebelum melakukan investasi mengenai keadaan perusahaan. Sinyal-sinyal tersebut dapat berupa informasi atau laporan mengenai kinerja atau kegiatan manajemen yang telah dilakukan guna merealisasikan keinginan pemegang saham. Kondisi perusahaan baik saat mengalami keuntungan maupun kerugian akan menjadi berita atau sinyal positif dan negatif. Apabila perusahaan memperoleh keuntungan maka akan memberi sinyal positif bagi investor, sebaliknya aabila perusahaan menderita kerugian akan menjadi sinyal negatif bagi investor atau pemegang saham (Ratih dan Damayanthi, 2016). Informasi mengenai kondisi perusahaan seperti laporan keuangan dan laporan kegiatan adalah suatu informasi yang penting sebelum perusahaan menawarkan sahamnya di pasar. Informasi tersebut dapat menjadi sinyal bagi calon investor mengenai kebijakan dividen yang akan dilakukan (Yuliawan dan Wirasedana, 2016). Teori sinyal dapat dikaitkan dengan asimetri 
Ni Putu Nugraheni dan Made Mertha. Pengaruh...

informasi, karena terjadinya kesenjangan informasi yang terjadi antara manajer dan investor. Manajer yang bekerja dan selalu berada di perusahaan dapat mengetahui prospek atau apa yang akan terjadi pada perusahaan. Sebaliknya, investor yang hanya mengetahui dari laporan yang diterbitkan perusahaan tidak dapat mengetahui dengan lengkap mengenai prospek atau apa yang terjadi di perusahaan (Gelb, 2000).

Kebijakan dividen adalah keputusan perusahaan mengenai seberapa banyak keuntungan periode tersebut yang akan dibagikan kepada pemegang saham sebagai dividen untuk pengembalian investasi yang telah dilakukan dan seberapa banyak pula yang akan disimpan kembali dalam perusahaan untuk digunakan sebagai laba ditahan guna pengembangan perusahaan (Brigham dan Houston, 2010:32). Pemilik perusahaan umumnya menginginkan agar sebagian keuntungan yang diperoleh perusahaan dibagikan sebagai dividen. Manajer keuangan harus dapat menjaga keseimbangan antara kebijakan dividen dengan kepentingan pemilik (Zahidda dan Sugiyono, 2017). Jumlah uang yang dibayarkan perusahaan dalam bentuk dividen berbeda dari satu bisnis ke bisnis lainnya. Kebijakan dividen yang telah diputuskan saat Rapat Umum Pemegang Saham (RUPS) akan menjadi acuan perusahaan untuk menentukan besaran dividen yang dibagikan kepada masing-masing pemegan saham (Kawshala dan Panditharathna, 2017). Karyawan, badan pengatur, dan konsumen juga memeiliki kepentingan kepada kebijakan dividen, bukan hanya pihak pemegang saham. (Khan et al., 2017). Kebijakan dividen juga didukung oleh teori sinyal, karena pengumuman pembagian dividen yang dilakukan perusahaan dapat menjadi sinyal 
yang postif bagi investor untuk memperoleh keuntungan. Sebaliknya, pengumuman tersebut juga dapat menjadi sinyal negatif apabila jumlah pembagian dividen yang dibagikan lebih kecil dibandingkan periode sebelumnya (Martono dan Harjito, 2005). Brigham dan Houston (2010) dalam Samrotun (2015) menyatakan bahwa terdapat tiga teori kebijakan dividen yaitu dividend irrelevance theory, bird in the hand theory, dan tax preference theory (teori preferensi pajak).

Likuiditas menurut Kasmir (2012:130) merupakan rasio yang digunakan untuk mengukur kemampuan perusahaan untuk memenuhi kewajiban-kewajiban jangka pendek. Kewajiban tersebut dapat berupa kewajiban perusahaan pada pihak eksternal maupun internal perusahaan. Perusahaan dengan tingkat likuiditas yang tinggi akan meningkatkan kemungkinan pembagian dividen dalam bentuk kas, sehingga menarik investor untuk menanamkan modalnya (Sari dan Hidayat, 2017). Salah satu rasio likuiditas, yaitu rasio lancar atau current ratio adalah rasio yang digunakan untuk mengukur mengukur kemampuan perusahaan dalam membayar kewajiban jangka pendek atau utang yang segera jatuh tempo pada saat ditagih secara keseluruhan dengan aktiva lancar yang dimiliki (Kasmir, 2012). Rasio kas atau cash ratio merupakan kemampuan perusahaan untuk memenuhi kewajiban jangka pendeknya (current liability) melalui sejumlah kas dan setara kas, seperti giro atau simpanan lain di bank yang dimiliki perusahaan yang dapat ditarik setiap saat. Kas yang dimaksud adalah uang yang dimiliki perusahaan yang disimpan dalam bentuk kas serta yang disimpan di bank dalam bentuk rekening koran. Setara kas adalah aktiva lancar yang dapat dengan mudah diuangkan 
Ni Putu Nugraheni dan Made Mertha. Pengaruh...

kembali. Kondisi ekonomi pada negara yang menjadi tempat perusahaan tersebut dapat memengaruhi atau merubah nilai setara kas tersebut (Brigham dan Houston, 2010).

Kepemilikan institusional adalah kepemilikan saham oleh pihak-pihak yang berbentuk institusi seperti yayasan, bank, perusahaan asuransi, perusahaan investasi, perusahaan berbentuk perseroan (PT), dan institusi lainnya (Edison, 2017). Sifat permasalahan keagenan akan ditentukan oleh struktur kepemilikan perusahaan. Permasalahan keagenan yang mungkin terjadi adalah konflik yang sering terjadi antara manajer dengan pemegang saham serta permasalahan antara pemegang saham pengendali (controlling shareholders) dengan pemegang saham minoritas (minority shareholders) (Azwari dan Fatah, 2016). Semakin besar kepemilikan institusi maka akan semakin besar kekuatan dari institusi tersebut untuk mengawasi manajemen. Akibatnya, akan memberikan dorongan yang lebih besar kepada manajemen untuk mengoptimalkan kinerja perusahaan (Nisa, 2017).

Berdasarkan latar belakang dan teori yang telah dikemukakan, maka kerangka konseptual dapat digambarkan sebagai berikut.

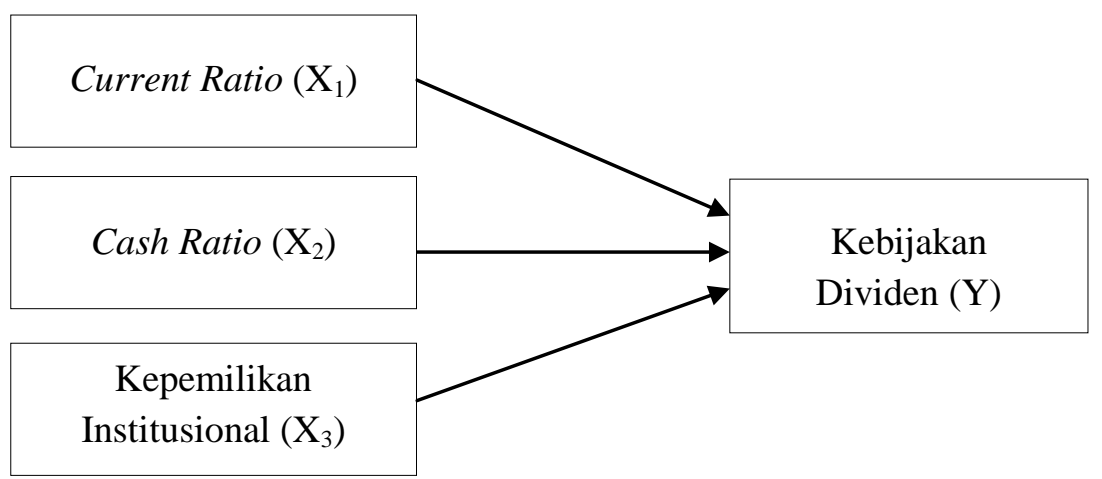

Gambar 1. Kerangka Konseptual

Sumber: Data diolah, 2018 
Perusahaan harus memiliki tingkat likuiditas yang baik agar dapat memenuhi kewajiban jangka pendeknya. Semakin tinggi tingkat likuiditas perusahaan yang dalam penelitian ini diproksikan dengan current ratio makan akan meningkatkan pembayaran dividen perusahaan kepada pemegang saham. Hal ini disebabkan karena semakin tinggi current ratio pada suatu perusahaan menunjukkan kemampuan perusahaan untuk membayarkan kewajiban jangka pendeknya dengan menggunakan aktiva lancar yang berupa kas, piutang, investasi jangka pendek, persediaan, dan beban dibayar di muka (Yosephine dan Tjun, 2016). Penelitian terdahulu yang dilakukan oleh Nufiati dan Suwitho (2015), Wahyuni (2015), Lestari dkk. (2016), dan Ahmed (2015) memperoleh hasil bahwa likuiditas yang diproksikan dengan current ratio berpengaruh positif terhadap kebijakan dividen. Semakin besar tingkat likuiditas, maka semakin besar pula kemampuan perusahaan untu membayar dividen. Berdasarkan teori dan penelitian terdahulu maka hipotesis yang dapat dirumuskan adalah sebagai berikut.

$\mathrm{H}_{1}$ : Likuiditas yang diproksikan dengan current ratio berpengaruh positif terhadap kebijakan dividen.

Cash ratio merupakan salah satu variabel penting yang dipertimbangkan manajemen dalam menetapkan dividen. Apabila nilai cash ratio pada suatu perusahaan bernilai lebih dari satu artinya perusahaan tersebut mampu untuk membayarkan kewajiban jangka pendeknya dengan kas dan setara kas yang dimiliki. Perusahaan yang kondisi likuiditasnya kurang baik cenderung menurunkan pembayaran dividennya, sebaliknya perusahaan yang memiliki tingkat likuiditas yang baik cenderung memberikan dividen lebih besar 
Ni Putu Nugraheni dan Made Mertha. Pengaruh...

(Yosephine dan Tjun, 2016). Penelitian terdahulu yang dilakukan oleh Shodikin (2018) dan Zaman (2018) memperoleh hasil bahwa likuiditas yang diproksikan dengan cash ratio berpengaruh positif terhadap kebijakan dividen. Semakin tinggi cash ratio yang dimiliki perusahaan menunjukkan jaminan yang lebih baik atas kewajiban lancar yang harus dibayarkan perusahaan. Berdasarkan teori dan penelitian terdahulu maka hipotesis yang dapat dirumuskan adalah sebagai berikut.

$\mathrm{H}_{2}$ : Likuiditas yang diproksikan dengan cash ratio berpengaruh positif terhadap kebijakan dividen.

Kepemilikan institusional merupakan pemegang saham terbesar dalam perusahaan dibandingkan dengan kepemilikan lainnya. Oleh karena itu pemilik saham dari pihak institusi memiliki wewenang lebih besar untuk melakukan kontrol dan pengawasan terhadap kinerja manajer sehingga dapat meminimalkan adanya masalah keagenan yang dapat terjadi, serta dapat meningkatkan keuntungan perusahaan. Peningkatan keuntungan ini akan berdampak pada peningkatan kebijakan dividen Dengan adanya pembayaran dividen yang tinggi maka akan mengurangi biaya yang disebut dengan agency cost (Chang et al., 2016). Penelitian terdahulu yang dilakukan oleh Kurniawati et al., (2015), Crane et al., (2016) dan (Jory et al., (2017) memperoleh hasil bahwa kepemilikan institusional berpengaruh positif terhadap kebijakan dividen. Tingkat kepemilikan institusional yang tinggi berdampak pada semakin baiknya kinerja manajemen guna meningkatkan laba perusahaan dan meningkatnya dividend payout ratio. 
Berdasarkan teori dan penelitian terdahulu maka hipotesis yang dapat dirumuskan adalah sebagai berikut.

$\mathrm{H}_{3}$ : Kepemilikan institusional berpengaruh positif terhadap kebijakan dividen.

\section{METODE PENELITIAN}

Pendekatan yang digunakan pada penelitian ini adalah pendekatan kuantitatif berbentuk asosiatif, yang hanya akan menjelaskan permasalahan yang akan diteliti yaitu mengetahui pengaruh variabel likuiditas dan kepemilikan institusional terhadap kebijakan dividen. Penelitian ini berlokasi di Bursa Efek Indonesia yang dapat diakses melalui website www.idx.co.id. Obyek penelitian pada penelitian ini adalah kebijakan dividen perusahaan manufaktur yang diuji dengan likuiditas dan kepemilikan institusional pada perusahaan manufaktur yang terdaftar di Bursa Efek Indonesia tahun 2014 sampai 2017.

Variabel-variabel yang digunakan meliputi variabel dependen yaitu kebijakan dividen $(\mathrm{Y})$ dan variabel independen yaitu current ratio $\left(\mathrm{X}_{1}\right)$, cash ratio $\left(\mathrm{X}_{2}\right)$, dan kepemilikan institusional $\left(\mathrm{X}_{3}\right)$. Kebijakan dividen $(\mathrm{Y})$ dalam penelitian ini diproksikan dengan Dividend Payout Ratio (DPR), yang dirumuskan sebagai berikut (Wiagustini, 2010:81).

$\mathrm{DPR}=\frac{\text { Dividen yang dibagikan }}{\text { Laba Bersih }} \times 100 \%$

Variabel independen current ratio $\left(\mathrm{X}_{1}\right)$ yang merupakan proksi dari likuiditas dirumuskan sebagai berikut (Hanafi dan Halim, 2014:75).

Current Ratio $=\frac{\text { Aktiva Lancar (Current Asset) }}{\text { Kewajiban Lancar (Current Liabilities) }} \times 100 \%$ 
Ni Putu Nugraheni dan Made Mertha. Pengaruh...

Variabel independen cash ratio $\left(\mathrm{X}_{2}\right)$ yang merupakan proksi dari likuiditas dirumuskan sebagai berikut.

Cash Ratio $=\frac{\text { Kas dan Setara Kas }}{\text { Kewajiban Lancar (Current Liabilities })} \times 100 \%$

Variabel independen kepemilikan institusional $\left(\mathrm{X}_{3}\right)$ dirumuskan sebagai berikut (Beiner et al., 2003).

Kepemilikan institusional $=\frac{\text { Kepemilikan Saham oleh Pihak Institusional }}{\text { Jumlah saham yang beredar }} \times 100 \%$

Populasi yang digunakan pada penelitian ini adalah seluruh perusahaan manufaktur di Bursa Efek Indonesia (BEI) periode pengamatan 2014-2017. Sampel dalam penelitian ini dipilih dengan menggunakan teknik non-probability sampling dan metode purposive sampling. Pengambilan sampel pada penelitian ini melalui beberapa kriteria sebagai berikut: (1) Perusahaan manufaktur yang terdaftar di Bursa Efek Indonesia dan konsisten mempublikasikan laporan tahunan periode 2014-2017; (2) Perusahaan manufaktur yang membagikan dividen selama periode 2014-2017; (3) Perusahaan yang mengungkapkan informasi mengenai struktur kepemilikan tahun 2014-2017. Metode pengumpulan data yang digunakan dalam penelitian ini adalah metode observasi nonpartisipan atau metode dokumentasi.

Teknik analisis data pada penelitian ini meliputi analisis statistik deskriptif, uji asumsi klasik, analisis regresi linear berganda, dan pengujian hipotesis. Statistik deskriptif digunakan untuk memberikan deskripsi suatu data yang dilihat dari rata-rata (mean), standar deviasi (standar deviation), dan maksimum-minimum. Standar deviasi digunakan untuk mengukur seberapa lama 
atau seberapa jauh penyimpangan data dari nilai rata-ratanya (mean), sehingga dengan mengamati nilai standar deviasi, maka dapat diketahui seberapa jauh range atau rentangan antara nilai maksimum dari masing-masing variabel (Ghozali, 2016;19). Setelah melakukan analisis statistik deskriptif, dilakukan pengujian asumsi klasik. Uji asumsi klasik terdiri dari uji normalitas, uji multikolinearitas, uji heteroskedastisitas, dan uji autokorelasi. Model persamaan regresi linear berganda yang digunakan yaitu:

$Y=\alpha+\beta_{1} X_{1}+\beta_{2} X_{2}+\beta_{3} X_{3}+\varepsilon$

Keterangan:

$\begin{array}{ll}\mathrm{Y} & : \text { Kebijakan dividen } \\ \alpha & : \text { Nilai konstanta } \\ \mathrm{X}_{1} & : \text { Current ratio } \\ \mathrm{X}_{2} & : \text { Cash ratio } \\ \mathrm{X}_{3} & : \text { Kepemilikan institusional } \\ \beta 1, \beta 2, \text { dan } \beta_{3} & : \text { Koefesien regresi } \\ \varepsilon & : \text { Standard error }\end{array}$

\section{HASIL DAN PEMBAHASAN}

Daerah atau wilayah penelitian yang digunakan dalam penelitian ini adalah Bursa Efek Indonesia (BEI), dengan perusahaan yang dipilih adalah perusahaan dalam sektor manufaktur. Sektor perusahaan yang jumlahnya paling banyak terdaftar di BEI adalah perusahaan manufaktur. perusahaan manufaktur memiliki proses produksi yang cukup kompleks dan investor cenderung berminat berinvestasi pada perusahaan manufaktur. Populasi perusahaan manufaktur yang terdaftar di Bursa Efek Indonesia (BEI) periode pengamatan 2014 sampai dengan 2017 berjumlah 157 perusahaan. Perusahaan manufaktur tersebut terdiri dari beberapa sektor yaitu, sektor industri dasar dan kimia berjumlah 71 perusahaan, sektor aneka 
Ni Putu Nugraheni dan Made Mertha. Pengaruh...

industri berjumlah 44 perusahaan, dan sektor industri barang konsumsi berjumlah 43 perusahaan. Seluruh populasi tersebut akan diseleksi kembali dengan kriteria purposive sampling yang telah ditentukan sebelumnya. Hasil analisis sampel dengan menggunkan purposive sampling dapat dilihat pada Tabel 1.

Tabel 1.

Hasil Seleksi Sampel Penelitian

\begin{tabular}{|c|c|c|}
\hline No & Kriteria & $\begin{array}{c}\text { Jumlah } \\
\text { Perusahaan }\end{array}$ \\
\hline & Jumlah perusahaan manufaktur yang terdaftar di Bursa Efek Indonesia & 157 \\
\hline 1 & $\begin{array}{l}\text { Perusahaan manufaktur yang tidak konsisten mempublikasikan laporan } \\
\text { tahunan periode } 2014-2017 \text {. }\end{array}$ & $(53)$ \\
\hline 2 & $\begin{array}{l}\text { Perusahaan manufaktur yang tidak membagikan dividen selama } \\
\text { periode 2014-2017. }\end{array}$ & (64) \\
\hline 3 & $\begin{array}{l}\text { Perusahaan yang tidak mengungkapkan informasi mengenai struktur } \\
\text { kepemilikan tahun 2014-2017. }\end{array}$ & (4) \\
\hline & Jumlah Sampel Penelitian & 36 \\
\hline & Jumlah Pengamatan Dalam Empat Tahun Penelitian & 144 \\
\hline
\end{tabular}

Sumber: Data diolah, 2018

Perusahaan yang masuk dalam populasi penelitian lalu diseleksi sesuai dengan kriteria yang telah ditetapkan sehingga sampel yang terpilih berjumlah 36 perusahaan selama 4 tahun dengan total 144 pengamatan.

Statistik deskriptif digunakan untuk memberikan deskripsi suatu data yang dilihat dari rata-rata (mean), standar deviasi (standar deviation), dan maksimum-minimum.

Tabel 2.

Hasil Statistik Deskriptif

\begin{tabular}{lrrrrr}
\hline \multicolumn{1}{c}{ Variabel } & N & Min. & Max. & Mean & $\begin{array}{c}\text { Std. } \\
\text { Deviation }\end{array}$ \\
\hline Kebijakan Dividen (Y) & 144 & 5,89 & 99,87 & 38,68 & 17,90 \\
Current Ratio $\left(\mathrm{X}_{1}\right)$ & 144 & 51,39 & 962,15 & 237,84 & 121,00 \\
Cash Ratio $\left(\mathrm{X}_{2}\right)$ & 144 & 0,48 & $1.925,26$ & 79,92 & 170,91 \\
Kepemilikan Institusional $\left(\mathrm{X}_{3}\right)$ & 144 & 5,14 & 98,90 & 68,33 & 15,53 \\
\hline Sumber: Data diolah, 2018 & & & & &
\end{tabular}


Nilai rata-rata kebijakan dividen adalah sebesar 38,68\%, nilai ini mendekati nilai minimumnya. Nilai minimum sebesar 5,89\% dimiliki oleh PT Pan Brothers Tbk pada tahun 2014. Nilai maksimum sebesar 99,87\% dimiliki oleh PT Hanjaya Mandala Sampoerna Tbk pada tahun 2015.

Nilai rata-rata current ratio adalah sebesar $237,84 \%$, nilai ini mendekati nilai minimumnya. Nilai minimum sebesar 51,39\% dimiliki oleh PT Multi Bintang Indonesia Tbk pada tahun 2014. Nilai maksimum sebesar 962,15\% dimiliki oleh PT Duta Pertiwi Nusantara pada tahun 2017.

Nilai rata-rata cash ratio adalah sebesar 79,92\%, nilai ini mendekati nilai minimumnya. Nilai minimum sebesar 51,39\% dimiliki oleh PT Multi Bintang Indonesia Tbk pada tahun 2014. Nilai maksimum sebesar 962,15\% dimiliki oleh PT Duta Pertiwi Nusantara pada tahun 2017.

Nilai rata-rata kepemilikan institusional adalah sebesar $68,30 \%$, nilai ini mendekati nilai maksimumnya. Nilai minimum sebesar $5,14 \%$ dimiliki oleh PT Hanjaya Mandala Sampoerna Tbk pada tahun 2014. Nilai maksimum sebesar 98,90\% dimiliki oleh PT Multi Bintang Indonesia Tbk pada tahun 2017.

Setelah melakukan pengujian statistik deskriptif, dilakukan uji asumsi klasik yang terdiri dari uji normalitas, uji multikolinearitas, uji autokorelasi dan uji heteroskedastisitas. 


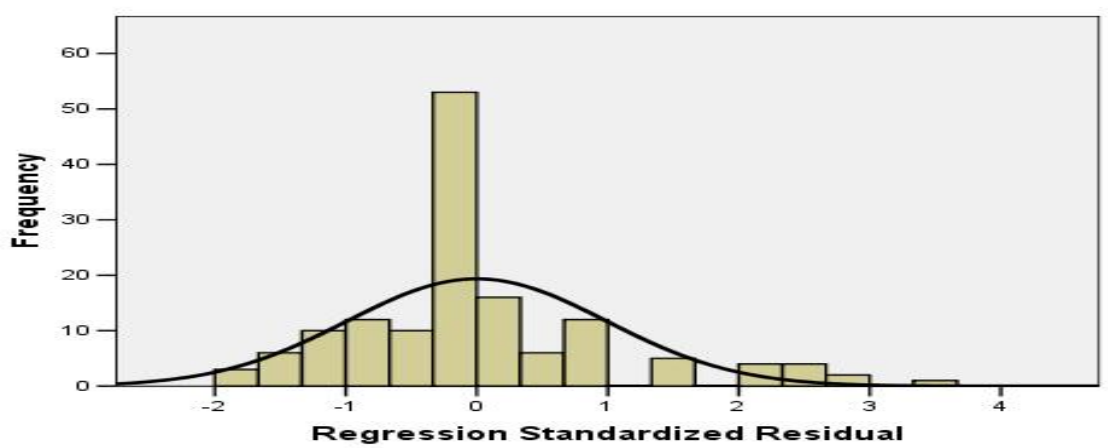

\section{Gambar 2. Hasil Uji Normalitas Grafik Histogram}

Sumber: Data diolah, 2018

Berdasarkan Gambar 2 hasil pengujian normalitas dapat dilihat sebaran data hasil uji normalitas grafik histogram tampak mengikuti kurva normal. Terdapat beberapa data yang merupakan data outlier, namun secara garis besar data yang digunakan terdistribusi mengikuti kurva normal, sehingga dapat disimpulkan bahwa data berdistribusi normal.

Tabel 3.

Hasil Uji Multikolinearitas

\begin{tabular}{lcc}
\hline \multicolumn{1}{c}{ Variabel } & \multicolumn{2}{c}{ Collinearity Statistics } \\
\cline { 2 - 3 } & Tolerance & VIF \\
\hline Current Ratio $\left(\mathrm{X}_{1}\right)$ & 0,949 & 1,053 \\
Cash Ratio $\left(\mathrm{X}_{2}\right)$ & 0,919 & 1,088 \\
Kepemilikan Institusional $\left(\mathrm{X}_{3}\right)$ & 0,939 & 1,068 \\
\hline Sumber: Data diolah, 2018 & &
\end{tabular}

Hasil uji multikolinearitas menunjukkan bahwa semua variabel bebas (independen) yang digunakan dalam penelitian ini memiliki nilai tolerance yang lebih besar dari 0,10 dan VIF yang kurang dari 10. Hasil perhitungan tersebut menunjukkan bahwa seluruh variabel bebas (independen) memiliki nilai tolerance lebih besar dari 0,10 dan VIF kurang dari 10. Berdasarkan hasil perhitungan tersebut dapat disimpulkan bahwa tidak adanya korelasi antar variabel bebas (independen) dan antar variabel bebas tidak terdapat multikolinearitas. 
Tabel 4.

Hasil Uji Autokorelasi

\begin{tabular}{cccccc}
\hline Model & R & R Square & $\begin{array}{c}\text { Adjusted R } \\
\text { Square }\end{array}$ & $\begin{array}{c}\text { Std. of Error } \\
\text { The Estimate }\end{array}$ & $\begin{array}{c}\text { Durbin- } \\
\text { Watson }\end{array}$ \\
\hline 1 & 0,397 & 0,158 & 0,140 & 16,60029 & 2,080 \\
\hline Sumber:
\end{tabular}

Sumber: Data diolah, 2018

Hasil uji autokorelasi dari nilai Durbin Watson hasil perhitungan model regresi yang telah dilakukan adalah sebesar 2,080. Sedangkan dari tabel Durbin Watson dengan signifikansi 0,05 dan jumlah data $\mathrm{N}=144$ serta $\mathrm{k}=3$ diperoleh nilai dL sebesar 1,6854 dan dU sebesar 1,7704. Nilai DW sebesar 2,080 terletak antara batas atas dU sebesar 1,7704 dan 4-dU sebesar 2,2296 sehingga koefisien autokorelasi sama dengan nol berarti tidak ada autokorelasi.

Tabel 5.

Hasil Uji Heteroskedastisitas

\begin{tabular}{lcl}
\hline \multicolumn{1}{c}{ Model } & Sig. & \multicolumn{1}{c}{ Keterangan } \\
\hline Current Ratio $\left(\mathrm{X}_{1}\right)$ & 0,167 & Tidak terjadi heterokedastisitas \\
Cash Ratio $\left(\mathrm{X}_{2}\right)$ & 0,266 & Tidak terjadi heterokedastisitas \\
Kepemilikan Institusional $\left(\mathrm{X}_{3}\right)$ & 0,997 & Tidak terjadi heterokedastisitas \\
\hline Sumber: Data diolah 2018 & &
\end{tabular}
Sumber: Data diolah, 2018

Hasil uji heteroskedastisitas yang telah dilakukan menunjukkan bahwa nilai signifikansi masing-masing variabel current ratio $\left(\mathrm{X}_{1}\right)$ sebesar 0,167 , variabel cash ratio $\left(\mathrm{X}_{2}\right)$ sebesar 0,266 dan variabel kepemilikan institusional $\left(\mathrm{X}_{3}\right)$ sebesar 0,997. Hal ini berarti nilai signifikansi masing-masing variabel lebih dari $\alpha=0,05$ sehingga dapat disimpulkan bahwa model regresi bebas dari gejala heterokedastisitas.

Analisis regresi linear berganda dilakukan untuk mengetahui besarnya pengaruh likuiditas yang diproksikan dengan current ratio $\left(\mathrm{X}_{1}\right)$ serta cash ratio $\left(\mathrm{X}_{2}\right)$ dan kepemilikan institusional $\left(\mathrm{X}_{3}\right)$ terhadap kebijakan dividen $(\mathrm{Y})$ di perusahaan manufaktur yang terdaftar di Bursa Efek Indonesia (BEI). 
Tabel 6.

Hasil Analisis Regresi Linear Berganda

\begin{tabular}{|c|c|c|c|c|c|c|}
\hline & \multirow[t]{2}{*}{ Model } & \multicolumn{2}{|c|}{$\begin{array}{c}\text { Unstandardized } \\
\text { Coefficients }\end{array}$} & \multirow{2}{*}{$\begin{array}{c}\begin{array}{c}\text { Standardized } \\
\text { Coefficients }\end{array} \\
\text { Beta }\end{array}$} & \multirow[t]{2}{*}{$\mathbf{t}$} & \multirow[t]{2}{*}{ Sig. } \\
\hline & & B & Std. Error & & & \\
\hline \multirow[t]{4}{*}{1} & (Constant) & 2,719 & 7,249 & & 0,375 & 0,708 \\
\hline & Current Ratio & 0,037 & 0,012 & 0,247 & 3,107 & 0,002 \\
\hline & Cash Ratio & $-0,013$ & 0,08 & $-0,124$ & $-1,528$ & 0,129 \\
\hline & Kep. Inst. & 0,414 & 0,092 & 0,359 & 4,482 & 0,000 \\
\hline $\mathrm{R}$ & & 0,397 & & & & \\
\hline & quare & 0,158 & & & & \\
\hline & justed R Square & 0,140 & & & & \\
\hline $\mathrm{F}$ & & 8,737 & & & & \\
\hline & nifikansi F & 0,000 & & & & \\
\hline
\end{tabular}

Tabel 6 hasil analisis regresi linear berganda menunjukkan persamaan regresi yang digunakan dalam penelitian ini adalah sebagai berikut.

$$
\mathrm{Y}=2,719+0,037 \mathrm{X}_{1}-0,013 \mathrm{X}_{2}+0,414 \mathrm{X}_{3}+\mathrm{e}
$$

Nilai konstanta $(\alpha)$ sebesar 2,719 artinya jika nilai current ratio, cash ratio, dan kepemilikan institusional dianggap konstan (tetap atau tidak ada perubahan) menyebabkan nilai kebijakan dividen sebesar 2,719 satuan. Nilai koefisien regresi current ratio sebesar 0,037 artinya jika nilai variabel current ratio mengalami peningkatakan sebesar 1 satuan, maka variabel kebijakan dividen akan mengalami kenaikan sebesar 0,037 satuan dengan asumsi variabel independen lainnya konstan. Nilai koefisien regresi variabel cash ratio sebesar 0,013 artinya jika nilai variabel cash ratio mengalami kenaikan sebesar 1 satuan, maka variabel kebijakan dividen mengalami penurunan sebesar 0,013 satuan dengan asumsi variabel independen lainnya konstan. Nilai koefisien regresi variabel kepemilikan institusional sebesar 0,414 artinya jika nilai variabel cash ratio mengalami kenaikan sebesar 1 satuan, maka variabel kebijakan dividen 
mengalami peningkatan sebesar 0,414 satuan dengan asumsi variabel independen lainnya konstan.

Tabel 7. Hasil Uji Koefisien Determinasi $\left(\mathbf{R}^{2}\right)$

\begin{tabular}{lcccc}
\hline Model & R & R Square & $\begin{array}{c}\text { Adjusted R } \\
\text { Square }\end{array}$ & $\begin{array}{c}\text { Std. Error of } \\
\text { The Estimate }\end{array}$ \\
\hline 1 & $.397^{\mathrm{a}}$ & .158 & .140 & 16.60029 \\
\hline Sumber: Data diolah, 2018 & & & &
\end{tabular}

Pengujian koefisien determinasi $\left(\mathrm{R}^{2}\right)$ berdasarkan Tabel 7 dapat dilihat nilai Adjusted $R$ Square sebesar 0,140 yang berarti bahwa sebesar $14 \%$ variasi kebijakan dividen yang diukur dengan dividend payout ratio (DPR) dapat dijelaskan oleh ketiga variabel independen. Variabel pertama yaitu current ratio, variabel kedua cash ratio, dan variabel ketiga yaitu kepemilikan institusional. Sedangkan sebesar $86 \%$ dipengaruhi oleh variabel lain yang tidak dimasukkan dalam model penelitian.

Hasil uji kelayakan model (uji F) pada tabel 6 dapat dilihat bahwa nilai p-value (Sig. F) adalah 0,000 lebih kecil dari nilai $\alpha=0,05$. Hal ini menunjukkan bahwa model yang digunakan dalam penelitian ini layak untuk digunakan sebagai alat analisis untuk menguji pengaruh variabel independen (current ratio, cash ratio, dan kepemilikan institusional) pada variabel dependan (kebijakan dividen).

Uji hipotesis atau uji statistik t pada Tabel 6 memperoleh hasil bahwa likuiditas yang diproksikan dengan current ratio berpengaruh positif dan signifikan terhadap kebijakan dividen, sehingga hipotesis pertama pada penelitian ini diterima. Diterimanya hasil hipotesis 1 dalam penelitian ini sejalan dengan teori sinyal yang mengemukakan bahwa tingginya nilai current ratio pada perusahaan menjadi sinyal atau isyarat bagi investor bahwa perusahaan berada 
Ni Putu Nugraheni dan Made Mertha. Pengaruh...

dalam kondisi atau tingkat likuiditas yang baik, sehingga akan mampu untuk memenuhi kewajibannya yaitu pembayaran dividen. Bird in the hand theory juga menyatakan bahwa keputusan untuk membagikan dividen kepada pemegang saham dapat mengurangi ketidakpastian risiko yang mungkin diterima investor. Hasil penelitian ini juga sejalan dengan penelitian terdahulu yang dilakukan oleh Lestari dkk. (2016) serta Sholikhah dan Hermanto (2017) yang memperoleh hasil bahwa likuiditas yang diproksikan dengan current ratio berpengaruh positif dan signifikan terhadap kebijakan dividen. Semakin tinggi tingkat current ratio akan semakin besar kemampuan perusahaan untuk memenuhi pembayaran dividennya.

Likuiditas yang diproksikan dengan cash ratio berpengaruh negatif dan tidak signifikan terhadap kebijakan dividen, sehingga hipotesis kedua pada penelitian ini ditolak. Tidak berpengaruhnya likuditas yang diproksikan dengan cash ratio terhadap kebijakan dividen menunjukkan bahwa cash ratio bukan merupakan faktor utama yang menjadi pertimbangan dalam memprediksi Dividen payout ratio. Selain itu, cash ratio tidak berpengaruh karena perusahaanperusahaan tersebut merupakan perusahaan go public yang mudah untuk mendapatkan pinjaman dari bank. Hal itu menyebabkan kemampuan perusahaan untuk membayar dividen tidak akan terganggu meskipun nilai cash ratio perusahaan tergolong rendah. Hasil penelitian ini juga dikemukakan oleh Hidayat (2016) menemukan hasil bahwa cash ratio tidak berpengaruh signifikan terhadap kebijakan dividen perusahan.

Kepemilikan institusional berpengaruh positif dan signifikan terhadap kebijakan dividen, sehingga hipotesis ketiga pada penelitian diterima. Hasil ini 
sejalan dengan teori keagenenan yang menyatakan bahwa prinsipal yaitu pemegang saham perusahaan memiliki wewenang untuk mengawasi kinerja manajemen perusahaan, karena telah berinvestasi pada perusahaan tersebut. Manajemen perusahaan yang berperan sebagai agen memiliki kewajiban untuk mengelola perusahaan sesuai prosedur dan keinginan pemegang saham, agar perusahaan mampu menghasilkan laba yang tinggi dan dapat memenuhi kewajiban pembayaran dividen kepada pemegang saham. Hal serupa diungkapkan oleh Nurwani (2018) dan (Kurniawati et al., (2015) yang memaparkan bahwa kepemilikan institusional berpengaruh positif dan signifikan terhadap kebijakan dividen. Institusional umunya memiliki mayoritas saham pada perusahaan, sehingga memiliki kekuatan yang lebih besar dibandingkan pemegang saham lainnya khususnya dalam mengendalikan dan mengawasi tindakan manajemen perusahaan.

Implikasi teoritis dari penelitian ini adalah dapat memberikan kontribusi mengenai pengaruh likuiditas dan kepemilikan institusional terhadap kebijakan dividen pada perusahaan manufaktur. Hasil uji dalam penelitian ini ditemukan bahwa dua dari tiga variabel independen berpengaruh signifikan terhadap kebijakan dividen. Implikasi praktis dari penelitian ini bagi investor yaitu sebagai bahan pertimbangan dan bukti empiris mengenai kebijakan dividen serta faktorfaktor yang memengaruhinya baik faktor dari dalam maupun luar perusahaan. Implikasi praktis bagi perusahaan adalah sebagai bahan pertimbangan untuk pengambilan keputusan keuangan perusahaan karena akan memengaruhi 
Ni Putu Nugraheni dan Made Mertha. Pengaruh...

kelangsungan hidup perusahaan dan memberikan sinyal kepada investor mengenai prospek perusahaan di masa mendatang.

\section{SIMPULAN}

Simpulan berdasarkan hasil penelitian yang telah dilakukan adalah likuiditas yang diproksikan dengan current ratio berpengaruh positif dan signifikan terhadap kebijakan dividen, likuiditas yang diproksikan dengan cash ratio berpengaruh negatif dan tidak signifikan terhadap kebijakan dividen, dan kepemilikan institusional berpegaruh positif dan signifikan terhadap kebijakan dividen.

Saran yang dapat diberikan pada penelitian ini terdiri dari saran kepada perusahaan, investor, dan peneliti selanjutnya. Bagi perusahaan, sebelum membuat keputusan mengenai kebijakan dividen, sebaiknya mempertimbangkan dahulu faktor-faktor yang dianggap berpengaruh terhadap besarnya dividen yang akan dibagikan, sehingga dapat saling menguntungkan antara investor dan perusahaan. Bagi calon investor diharapkan dapat menggunakan penelitian ini sebagai bahan pertimbangan sebelum melakukan investasi pada suatu perusahaan. Bagi peneliti selanjutnya diharapkan dapat menambahkan variabel independen lainnya seperti profitabilitas karena variabel independen dalam penelitian ini hanya dapat menjelaskan variabel dependen sebesar 14\%, sehingga sisanya sebesar $86 \%$ dijelaskan oleh variabel lain yang tidak digunakan dalam penelitian ini. 


\section{REFERENSI}

Ahmed, I. E. 2015. Liquidity, Profitability and The Dividends Payout Policy. World Review of Business Research, 5(2), 73-85.

Anthony, Robert N. dan Govindarajan, Vijay. 2012. Management Control System. Jakarta: Salemba Empat.

Audriene, Dinda. 2017. Laba Anjlok, Vale Putuskan Tak Bagi Dividen. https://www.cnnindonesia.com/ekonomi/20170327172019-92-203075/labaanjlok-vale-putuskan-tak-bagi-dividen Diakses tanggal 7 Februari 2018.

Azwari, P. C., \& Fatah, I. R. 2016. Masalah Keagenan Pada Struktur Kepemilikan Perusahaan Keluarga di Indonesia. Jurnal Ilmu Akuntansi, 9(2), 173-184. https://doi.org/10.15408/akt.v9i2.4021

Bamaisyarah, R. Y., \& Fuadati, S. R. 2017. Pengaruh Likuiditas, Aktivitas, dan Ukuran Perusahaan Terhadap Profitabilitas Perusahaan Pertambangan di BEI. Jurnal Ilmu Dan Riset Manajemen, 6(3), 1-15.

Beiner, S., Drobetz, W., Schmid, F., \& Zimmermann, H. 2003. Is Board Size an Independent Corporate Governance Mechanism? Financial Valuation and Risk Management, 89(4), 1-32. https://doi.org/10.1111/j.00235962.2004.00257.x

Brigham, Eugene F. dan Houston, Joel F. 2010. Dasar-Dasar Manajemen Keuangan, Buku 1 Edisi 11. Jakarta: Salemba Empat.

Bozec, Y., \& Laurin, C. 2008. Large Shareholder Entrenchment and Performance: Empirical Evidence from Canada. Journal of Business Finance and Accounting, 35(1), 25-49. https://doi.org/10.1111/j.1468-5957.2007.02066.x

Chang, K., Kang, E., \& Li, Y. 2016. Effect of institutional ownership on dividends: An agency-theory-based analysis. Journal of Business Research, 69(7), 2551-2559. https://doi.org/10.1016/j.jbusres.2015.10.088

Crane, A. D., Michenaud, S., \& Weston, J. P. 2016. The Effect of Institutional Ownership on Payout Policy: Evidence from Index Thresholds. Review of Financial Studies, 29(6), 1377-1408. https://doi.org/10.1093/rfs/hhw012

Destrianita. 2017. Laba Usaha Turun, Anak Usaha Lippo Karawaci Tetap Bagi Dividen. https://bisnis.tempo.co/read/857969/laba-usaha-turun-anak-usahalippo-karawaci-tetap-bagi-dividen Diakses tanggal 7 Februari 2018.

Edison, A. 2017. Struktur Kepemilikan Asing, Kepemilikan Institusional dan Kepemilikan Manajerial Pengaruhnya Terhadap Luas Pengungkapan 
Corporate Social Responsibility CSR) (Studi Empiris Pada Perusahaan Sektor Utama Yang Terdaftar Di Bursa Efek Indonesia Tahun 2013-2014. Jurnal Bisnis Dan Manajemen Fakultas Ekonomi Universitas Widyatama, 11(2), 164-175.

Gelb, D. S. 2000. Corporate Signaling with Dividends, Stock Repurchases, and Accounting Disclosures: An Empirical Study. Journal of Accounting, Auditing \& Finance, 15(2), 99-120. https://doi.org/10.1177/0148558X0001500201

Ghozali, Imam. 2016. Aplikasi Analisis Multivariate Dengan Program IBM SPSS 23. Semarang: Badan Penerbit Universitas Diponegoro.

Hanafi, Mamduh M. dan Halim, Abdul. 2014. Analisis Laporan Keuangan Edisi Tujuh. Yogyakarta: UPP STIM YKPN.

Hidayat, M. 2016. Pengaruh Earning Per Share dan Cash Ratio Terhadap Dividen Payout Ratio Dengan Asset Growth Sebagai Variabel Moderasi Pada Sektor Industri Barang Konsumsi di BEI Periode 2009-2012. Journal Unrika, 8(1), $1-15$.

Jensen, M. C., \& Meckling, W. H. 1976. Theory Of The Firm: Managerial Behavior, Agency Costs and Ownership Structure. Journal Financial of Economics, 3(4), 305-360. https://doi.org/10.1016/0304-405x(76)90026-x

Jory, S. R., Ngo, T., \& Sakaki, H. 2017. Institutional Ownership Stability and Dividend Payout Policy. Managerial Finance, 43(10), 1170-1188. https://doi.org/10.1108/MF-09-2016-0272

Kasmir. 2012. Pengantar Manajemen Keuangan. Jakarta: Kencana Prenada Media Group.

Kawshala, H., \& Panditharathna, K. 2017. The Effect of Dividend Policy on Corporate Profitability: An Empirical Study on Beverage, Food and Tobacco Industry in Sri Lanka. International Journal of Scientific and Research Publications, 7(8), 542-546. Retrieved from www.ijsrp.org

Khan, Y., Ali, L., Batool, S., \& Ali, A. 2017. Growth \& Profitability of Private Commercial Banks: Major Indicator of Its Dividend Policy. American Journal of Operations Management and Information Systems, 2(4), 92-96. https://doi.org/10.11648/j.ajomis.20170204.12

Kurniawati, L., Manalu, S., \& Octavianus, R. J. N. 2015. Pengaruh Kepemilikan Institusional Terhadap Kebijakan Dividen, Dan Harga Saham. Jurnal Manajemen, 15(1), 59-74. 
Lestari, K. F., Tanuatmodjo, H., \& Mayasari. 2016. Pengaruh Likuiditas dan Profitabilitas Terhadap Kebijakan Dividen. Journal of Business Management Education, 1(2), 11-16.

Martono dan Harjito, D. Agus. 2011. Manajemen Keuangan Edisi Kedua, Cetakan Pertama. Yogyakarta: Penerbit Ekonisia.

Mehrani, S., Moradi, M., \& Eskandar, H. 2011. Ownership Structure And Dividend Policy: Evidence from Iran. African Journal of Business Management, 5(17), 7516-7525. https://doi.org/10.5897/AJBM11.468

Michaely, R., \& Qian, M. 2017. Stock Liquidity and Dividend Policy: Dividend Policy Changes Following an Exogenous Liquidity Shock. SSRN Electronic Journal, 18(3), 1-42. https://doi.org/10.2139/ssrn.2894164

Nisa, H. 2017. Pengaruh Kepemilikan Institusional dan Leverage Terhadap Kebijakan Dividen Dengan Free Cash Flow Sebagai Variabel Moderasi Pada Perusahaan Manufaktur di BEI Periode 2011-2015. JOM Fekon, 4(1), 387401.

Nufiati, N. M. B., \& Suwitho. 2015. Pengaruh Profitabilitas Dan Likuiditas Terhadap Kebijakan Dividen Kas Pada Perusahaan PEFINDO 25. Jurnal Ilmu Dan Riset Manajemen, 4(3), 1-18. https://doi.org/10.1111/14685930.00209

Nurwani. 2018. Pengaruh Kepemilikan Institusional, Kepemilikan Manajerial dan Profitabilitas Terhadap Kebijakan Dividen pada Perusahaan Manufaktur. EJournal Economics, 3(1), 1141-1151. Retrieved from https://ejournal.unsrat.ac.id/index.php/emba/article/view/7928

Ratih, I. D. A., \& Damayanthi, I. G. A. E. 2016. Kepemilikan Manajerial dan Profitabilitas Pada Nilai Perusahaan dengan Pengungkapan Tanggungjawab Sosial Sebagai Variabel Pemoderasi. E-Jurnal Akuntansi Universitas Udayana, 14(2), 1510-1538. https://doi.org/10.1021/ie403070u

Samrotun, Y. C. 2015. Kebijakan Dividen dan Faktor-Faktor yang Mempengaruhinya. Jurnal Paradigma, 13(1), 92-103.

Sari, N. K. A. P., \& Budiasih, I. G. A. N. 2016. Pengaruh Kepemilikan Managerial, Kepemilikan Institusional dan Profitabilitas pada Kebijakan Deviden. E-Jurnal Akuntansi Universitas Udayana, 15(3), 2439-2466.

Sari, S. W., \& Hidayat, I. 2017. Pengaruh Struktur Modal, Likuiditas Terhadap Profitabilitas Perusahaan Makanan dan Minuman Di BEI. Jurnal Ilmu Dan Riset Manajemen, 6(6), 1-18. 
Shleifer, A., \& Vishny, R. W. (1997). A Survey of Corporate Governance. The Journal of Finance, 52(2), pp.737-783. https://doi.org/10.1111/j.15406261.1997.tb04820.x

Shodikin, A. 2018. Pengaruh Current Ratio (CR), Cash Ratio, Debt To Equity Ratio (DER), dan Return On Investment (ROI) Terhadap Dividend Per Share (Studi Pada Perusahaan Property Dan Real Estate yang Tercatat Di BEI). EJournal UMM, 106(11), 1-8.

Sholikhah, K. A., \& Hermanto, S. B. 2017. Pengaruh Likuiditas, Profitabilitas, Leverage, Cash Position, dan Growth Terhadap Kebijakan Dividen. Jurnal Ilmu Dan Riset Akuntansi, 6(5), 1903-1921.

Villalonga, B., \& Amit, R. 2006. How Do Family Ownership, Control and Management Affect Firm Value? Journal of Financial Economics, 80(2), 385-417. https://doi.org/10.1016/j.jfineco.2004.12.005

Wahyuni, N. L. A. 2015. Pengaruh Profitabilitas dan Likuiditas Terhadap Besarnya Dividen yang Dibagikan Kepada Pemegang Saham Pada Perusahaan Manufaktur Yang Terdapat di BEI. Jurnal Jurusan Pendidikan Ekonomi, 5(1), 1.

Wiagustini, Ni Luh Putu. 2010. Dasar-Dasar Manajemen Keuangan. Denpasar: Udayana University Press.

Wicaksono, S., \& Nasir, M. 2014. Faktor-Faktor yang Mempengaruhi Kebijakan Dividen Pada Perusahaan Manufaktur yang Terdaftar di BEI Periode Tahun 2011-2013. Diponegoro Journal Of Accounting, 3(4), 1-13.

Yasmita, N. P. L., \& Widanaputra, A. A. G. P. 2018. Pengaruh Asimetri Informasi Pada Kebijakan Dividen dengan Investment Opportunity Set Sebagai Variabel Pemoderasi. E-Jurnal Akuntansi Universitas Udayana, 22(3), 2040-2064. https://doi.org/https://doi.org/10.24843/EJA.2018.v22.i03.p15

Yosephine, F., \& Tjun, L. T. 2016. Pengaruh Cash Ratio, Return on Equity, dan Ukuran Perusahaan terhadap Kebijakan Dividen: Studi Empiris pada Perusahaan yang Listing di Bursa Efek Indonesia Periode 2013-2014. Jurnal Akuntansi, 8(2), 237-269.

Yuliawan, K. T., \& Wirasedana, I. W. P. 2016. Kepemilikan Institusional Memoderasi Pengaruh Manajemen Laba menjelang Initial Public Offering Pada Return Saham. E-Jurnal Akuntansi Universitas Udayana, 14(2), 13961422.

Zahidda, D., \& Sugiyono. 2017. Pengaruh Profitabilitas, Likuiditas, Posisi Kas Terhadap Kebijakan Dividen Pada Perusahaan Food Beverages. Jurnal Ilmu 
Dan Riset Manajemen, 6(2), 1-16.

Zaman, D. R. 2018. Effect of Financial Performance on Dividend Policy in Manufacturing Companies in Indonesia Stock Exchange. Integrated Journal of Business and Economics, 2(1), 49-63. 